Research Article

\title{
Modulatory effects of Tabebuia impetiginosa (Lamiales, Bignoniaceae) on doxorubicin-induced somatic mutation and recombination in Drosophila melanogaster
}

\author{
Neila C. de Sousa ${ }^{1,2}$, Alexandre A.A. de Rezende ${ }^{2}$, Regildo M.G. da Silva ${ }^{2}$, Zaira R. Guterres ${ }^{2}$, Ulrich Graf ${ }^{3}$, \\ Warwick E. Kerr² and Mário A. Spanó ${ }^{2}$ \\ ${ }^{1}$ Universidade Federal de Goiás, Campus Catalão, Catalão, GO, Brazil. \\ ${ }^{2}$ Instituto de Genética e Bioquímica, Universidade Federal de Uberlândia, Uberlândia, MG, Brazil. \\ ${ }^{3}$ Physiology and Animal Husbandry, Institute of Animal Sciences, ETH Zurich, Switzerland.
}

\begin{abstract}
The wing Somatic Mutation and Recombination Test (SMART) in D. melanogaster was used to study genotoxicity of the medicinal plant Tabebuia impetiginosa. Lapachol (naphthoquinone) and $\beta$-lapachone (quinone) are the two main chemical constituents of $T$. impetiginosa. These compounds have several biological properties. They induce apoptosis by generating oxygen-reactive species, thereby inhibiting topoisomerases (I and II) or inducing other enzymes dependent on NAD(P)H:quinone oxidoreductase 1, thus affecting cell cycle checkpoints. The SMART was used in the standard (ST) version, which has normal levels of cytochrome P450 (CYP) enzymes, to check the direct action of this compound, and in the high bioactivation (HB) version, which has a high constitutive level of CYP enzymes, to check for indirect action in three different $T$. impetiginosa concentrations $(10 \%, 20 \%$ or $40 \% \mathrm{w} / \mathrm{w})$. It was observed that $T$. impetiginosa alone did not modify the spontaneous frequencies of mutant spots in either cross. The negative results observed prompted us to study this phytotherapeuticum in association with the reference mutagen doxorubicin (DXR). In co-treated series, T. impetiginosa was toxic in both crosses at higher concentration, whereas in the HB cross, it induced a considerable potentiating effect (from $\sim 24.0$ to $95.0 \%$ ) on DXR genotoxity. Therefore, further research is needed to determine the possible risks associated with the exposure of living organisms to this complex mixture.
\end{abstract}

Key words: genotoxicity, synergistic effect, somatic mutation and recombination test - SMART, toxicity, wing spot test.

Received: August 20, 2008; Accepted: November 24, 2008.

\section{Introduction}

Tabebuia impetiginosa (Lamiales, Bignoniaceae), popularly known as Ipê, pau d'arco, pink trumpet tree, taheebo and lapacho rosado, is a medicinal plant, native to tropical rain forests and the 'cerrado' (savannah) throughout Central and South America. Tabebuia spp is used in the construction of external structures, stairs and parquets (Algranti et al., 2005). Tabebuia impetiginosa (Martius ex DC) Standley has been used in folk medicine as a diuretic and astringent, as well as for treating ulcers, syphilis, gastrointestinal problems, candidiasis, cancer, diabetes, prostatitis, constipation and allergies (Almeida, 1993; Park et al., 2003).

The bark of the Tabebuia spp stem is a source of furanonaphthoquinones, quinines, naphthoquinones, ben-

Send correspondence to Mário Antônio Spanó. Laboratório de Mutagênese, Instituto de Genética e Bioquímica, Universidade Federal de Uberlândia, Campus Umuarama, 38400-902 Uberlândia, MG, Brazil. E-mail: maspano@ufu.br. zoic acid, benzaldehyde derivatives, cyclopentene dialdehyde and flavonoids (Zani et al., 1991; Koyama et al., 2000; Park et al., 2003). Further constituents from the bark of $T$. impetiginosa are iridoid glycosides, lignan glycosides, isocoumarin glycosides, phenylethanoid glycosides and phenolic glycosides (Warashina et al., 2004; 2005; 2006). Lapachol [2-hydroxy-3-(3-methyl-2-butenyl)-1,4-naphtalene-dione], naphthoquinone and its derivative $\beta$-Lapachone (2,2-dimethyl-3,4-dihydro-2,4-benzo[h]chromene-5,6-dione), which possess biologically active properties, can be isolated from $T$. impetiginosa (Park et al., 2003). The inner bark extract of this plant potently inhibited cell proliferation and DNA synthesis (Son et al., 2006). The stereo-selective synthesis of biologically active naphthoquinones from Tabebuia avellanedae, as described by Yamashita et al. (2007), displayed potent cytotoxicity against several human tumor cell lines, whereas it showed lower cytotoxicity against certain normal human cell lines when compared with that of mitomycin. A synthetic version of the natural product $\beta$-lapachone has been 
isolated from T. impetiginosa, and has also demonstrated promising anticancer activity (Savage et al., 2008).

The T. impetiginosa bark compounds lapachol and $\beta$-lapachone are reportedly antipsoriatic, antifungal, antimicrobial, antioxidant, antiviral, anti-inflammatory, antiulcerogenic, anticarcinogenic, antibacterial and antimalarial, besides possessing antitrypanosomal activity and acting as a chemoprophylactic against infection by Schistosoma mansoni cercariae (Anesini and Perez, 1993; Müller et al., 1999; Fonseca et al., 2003; Park et al., 2003, 2005, 2006; Menna-Barreto et al., 2005). An overview of Lapachol is presented by Hussain et al. (2007).

The anthracycline antibiotic doxorubicin is a topoisomerase II inhibitor (Swift et al., 2008) and a generator of oxygen free radicals (Doroshow, 1983). Previous studies have shown that DXR induces preferentially homologous recombination compared with mutational events in somatic cells of D. melanogaster (Lehmann et al., 2003; Fragiorge et al., 2007; Pereira et al., 2008; Silva et al., 2008; Valadares et al., 2008).

The wing spot test in Drosophila melanogaster (Somatic Mutation and Recombination Test - SMART) is a versatile, efficient and inexpensive short-term in vivo genotoxicity assay for the detection of genotoxicity induced by single pure compounds and complex mixtures. For this reason, it is also ideally suited for anti-genotoxicity studies as well as for investigations into the modulation of genotoxicity (Graf et al., 1998). It was developed to detect the loss of heterozygosity of the marker genes expressed phenotypically in the trichomes of the fly's wings. It provides rapid information on the ability of genotoxic agents to induce (or of antigenotoxic agents to inhibit) point mutations, chromosome breaks or losses during cell division, or the rearrangement related to mitotic recombination (Graf et al., 1984; 1989; Guzmán-Rincón and Graf, 1995; Vogel et al., 1999). Previous studies have shown that SMARTs are best suited for the detection of recombinogenic activity of genotoxic chemicals (Spanó et al., 2001). The standard version presents basal levels of cytochrome P450 (CYP) enzymes (Graf et al., 1989), whereas the high bioactivation version presents a high level of CYP (Graf and van Schaik, 1992) with the capacity to activate promutagens and procarcinogens enzymatically (Frölich and Würgler, 1990; Graf and Singer, 1992; Graf and van Schaik, 1992).

For antigenotoxicity and modulatory studies, the SMART assays offer a wide variety of flexible protocols for the application of test compounds (Graf et al., 1998). Owing to these advantages, SMART has been adopted for the genotoxicity / antigenotoxicity / modulatory testing of natural products (Sousa et al., 2003; Fragiorge et al., 2007; Pereira et al., 2008; Valadares et al., 2008).

Due to the wide distribution of the genus Tabebuia, consisting of about 20 species of trees, its use in folk medicine and the lack of information related to genetic toxicology, it is important to evaluate: i) the genotoxicity of its leaves, stem bark, pods, and seed extracts, as these may be potentially mutagenic, clastogenic, recombinogenic, and/or carcinogenic in man; ii) its modulatory effects, which enable its use as a chemotherapeutic coadjuvant.

The aim of this study was to evaluate the genotoxic potential of a commercially available product of $T$. impetiginosa bark and stem, since this is a natural product widely used in folk medicine in Brazil. The negative results observed with $T$. impetiginosa in the somatic cells of $D$. melanogaster prompted us to study this phytotherapeuticum in association with the reference mutagen DXR.

\section{Material and Methods}

\section{Chemical compounds and media}

A commercial preparation of the powdered bark and trunk of T. impetiginosa - Ipê Roxo Max ${ }^{\circledR}$ - was obtained from Saúde na Rede (Rio de Janeiro, RJ, Brazil). Doxorubicin (DXR) - Korea United Pharm Inc Co., Ltd. (Seoul, Korea) - was obtained from Meizler Comércio Internacional S.A. (Barueri, SP) and dissolved in ultrapure water in the absence of light. Ultrapure water, used as a negative control, was obtained from a MilliQ system (Millipore, Vimodrone, Milan, Italy). All solutions were always freshly prepared in ultrapure water immediately before use.

\section{Drosophila strains}

Three strains were used for crossbreeding: (i) multiple wing hairs (mwh): $m w h / m w h$; (ii) flare-3 $\left(f l r^{3} / I n\right.$ (3LR)TM3, rip ${ }^{p}$ sep l(3)89Aabx ${ }^{34 e}$ e $\left.B d^{S}\right)$; and (iii) ORR; flare-3 (ORR/ORR; $\mathrm{flr}^{3} / \mathrm{In} \quad(3 \mathrm{LR}) \mathrm{TM} 3, \mathrm{rip}^{p}$ sep l(3) $89 \mathrm{Aabx}^{34 e}$ e $B d^{S}$ ). More details on the genetic markers are given by Lindsley and Zimm (1992).

\section{Crossbreedings for the SMART assays}

Two crosses were carried out: (1) the Standard (ST) cross, where flare- 3 females were mated with mwh males (Graf et al., 1989); and (2) the High Bioactivation (HB) cross, where ORR; flare-3 females were mated with mwh males (Graf and van Schaik, 1992). The latter cross is highly sensitive to promutagens and procarcinogens due to the increased level of CYP. The ORR; flare- 3 strain has chromosomes 1 and 2 substituted in the wild DDT-resistant Oregon R (R) strain, and the gene (R) of chromosome 2 is responsible for the high constitutive level of CYP enzymes (Dapkus and Merrell, 1977; Frölich and Würgler, 1989).

Two types of individuals emerge from both ST and $\mathrm{HB}$ crossbreeding: marker trans-heterozygous $(\mathrm{MH})$ flies $\left(m w h+/+f l r^{3}\right)$ and balancer-heterozygous (BH) flies ( $m w h$ $\left.+/+T M 3, B d^{S}\right)$. The latter can be distinguished phenotypically by its serrated wings.

\section{Experimental procedure}

After two days of crossbreeding, the couples were transferred to the oviposition medium (an agar-agar base 
$(3 \% \mathrm{w} / \mathrm{v})$ and a layer of fermenting live baker's yeast supplemented with sucrose) where they remained for $8 \mathrm{~h}$, after which they were discarded. Third instar larvae $(72 \mathrm{~h} \pm 4 \mathrm{~h})$ were transferred to glass vials containing different quantities $(10 \%, 20 \%$ or $40 \% \mathrm{w} / \mathrm{w})$ of powdered bark and stem of T. impetiginosa mixed with mashed potato flakes (Yoki Alimentos S. A. - São Bernardo do Campo, SP, Brazil), lightly ground by using a mortar and pestle, and rehydrated with $5 \mathrm{~mL}$ of ultrapure water (to evaluate the genotoxic effects of $T$. impetiginosa $)$ or DXR $\left(0.125 \mathrm{mg} \mathrm{mL}^{-1}\right)$ (to evaluate the modulatory effects of T. impetiginosa). Negative (ultrapure water) and positive (DXR $0.125 \mathrm{mg} \mathrm{mL}^{-1}$ ) controls were included in both experiments.

The larvae were kept in the culture media at a temperature of $25{ }^{\circ} \mathrm{C}$ and relative humidity of $65 \%$ until the adult stage. Emerged adult flies were stored in $70 \%$ ethanol. The wings were mounted on glass slides and analyzed by optical microscopy with $400 \mathrm{x}$ magnification, revealing single spots (mwh or flr) or twin spots (mwh and flr). For further details of this procedure, see Graf et al. (1984).

\section{Evaluation of the data and statistical analysis}

The frequency of spots per fly in each series was compared with the negative control to evaluate genotoxic effects. In order to assess antigenotoxic effects, the frequency of spots per fly in each treated series was compared with the positive control. Statistical comparisons were made using the SMART computer program, which uses the chi-square test for proportions and allows for a multi-decision procedure (Frei and Würgler, 1988). For final statistical analysis of all positive outcomes, the non-parametric Mann-Whitney $U$-test with significance levels $\alpha=\beta=0.05$ was used in order to exclude false positives (Frei and Würgler, 1995). Based on clone induction frequencies per $10^{5}$ cells, recombinogenic activity was calculated as: mutation frequencies $\left(F_{\mathrm{M}}\right)=$ frequencies clones BH flies/frequencies clones $\mathrm{MH}$ flies; recombination frequencies $\left(F_{\mathrm{R}}\right)=1-F_{\mathrm{M}}$. Frequencies of total spots $\left(F_{\mathrm{T}}\right)=$ total spots in MH flies (considering $m w h$ and $f l r^{3}$ spots) $/$ No. of flies; mutation $=F_{\mathrm{T}} \times F_{\mathrm{M}}$; recombination $=F_{\mathrm{T}} \mathrm{X}$ $F_{\mathrm{R}}$ (Santos et al., 1999; Sinigaglia et al., 2006). Based on control-corrected spot frequencies per $10^{5}$ cells, the percentages of $T$. impetiginosa inhibition were calculated as: (DXR alone - T. impetiginosa plus DXR / DXR alone) x 100 (Abraham, 1994).

\section{Results}

Prior to genotoxicity assessment, the commercial preparation of the powdered bark and stem of $T$. impetiginosa was submitted to a dose-range test (data not shown), which demonstrated that $T$. impetiginosa presented toxicity in larvae fed for $48 \mathrm{~h}$. The non-toxic (10 and 20\%) and less-toxic (40\%) concentrations from all those tested were used to perform mutagenic/recombinogenic evaluation. $T$. impetiginosa $(10 \%, 20 \%$ or $40 \% \mathrm{w} / \mathrm{w})$ alone, the reference mutagen (DXR $0.125 \mathrm{mg} \mathrm{mL}^{-1}$ ) alone and T. impetiginosa $(10 \%, 20 \%$ or $40 \% \mathrm{w} / \mathrm{w})$ in association (co-treatment) with DXR $0.125 \mathrm{mg} \mathrm{mL}^{-1}$ were assayed twice in ST and HB crossbreeds. Concurrent negative and positive controls were also included. Since no statistical differences were found among the results of individual experiments, data were pooled. Tables 1 and 2 present the results observed with $\mathrm{MH}$ and BH flies of, respectively, the ST and HB crossbreeds. To assess the statistical significance of the frequency of mutant spots observed among flies treated with T. impetiginosa, the results were compared with data from the corresponding negative controls. No significant differences in the frequency of mutant spots were observed among flies treated with all the T. impetiginosa concentrations and the negative control in ST and HB crossbreeds MH flies.

To evaluate the statistical significance of co-treatment series, the results of the different $T$. impetiginosa concentrations in association with DXR were compared with the positive control.

In the MH flies of the ST crossbreed, the frequency of mutant spots observed between those co-treated with $T$. impetiginosa $10 \%$ or $20 \%$ and DXR showed no statistical significance, but $T$. impetiginosa $40 \%$ in association with DXR presented a weak positive diagnosis, displaying a $36.63 \%$ inhibition of DXR genotoxicity. The wings of BH flies were mounted and analyzed whenever a positive response was obtained in the MH offspring. In this case, as no significant differences in the frequency of mutant spots were observed among flies co-treated with $T$. impetiginosa $10 \%$ or $20 \%$ and DXR compared to flies treated with DXR alone, the $\mathrm{BH}$ flies from these treated series were not analyzed. When the BH flies co-treated with $T$. impetiginosa $40 \% \mathrm{w} / \mathrm{w}$ and DXR were checked, an inhibitory effect against the frequency of total spots $(26.08 \%)$ was observed. Comparisons between the clone induction frequencies per $10^{5}$ cells observed in the $\mathrm{MH}$ and $\mathrm{BH}$ flies of the co-treated series with DXR and T. impetiginosa $40 \%$, were done to quantify the mutagenic and recombinogenic potential of $T$. impetiginosa. The results showed that the genotoxicity in MH flies was mainly due to mitotic recombination $(\sim 90 \%)$ (Table 1).

In MH flies of the HB crossbreed, the frequency of mutant spots observed among those co-treated with $T$. impetiginosa $10 \%, 20 \%$ or $40 \%$ and DXR showed a positive increase (respectively, 94.61; 76.25 and $23.75 \%$ ) in the total number of spots, when compared with DXR alone. When the BH flies treated with T. impetiginosa $10 \% \mathrm{w} / \mathrm{w}$ in association with DXR were checked, a positive increase $(119.33 \%)$ in the total number of spots was noted. When comparisons between the clone induction frequencies per $10^{5}$ cells observed in the $\mathrm{MH}$ and $\mathrm{BH}$ flies of the co-treated series with DXR and all concentrations of $T$. impetiginosa, were done, the results showed that the enhancement of genotoxicity in $\mathrm{MH}$ flies was mainly due to mitotic recombination (87\%-90\%) (Table 2). 
Table 1 - Summary of results obtained with the Drosophila Wing spot test (SMART) in the marker trans-heterozygous (MH) and balancer-heterozygous (BH) progeny of the standard (ST) cross after chronic treatment of larvae with Tabebuia impetiginosa (Ti) and doxorubicin (DXR).

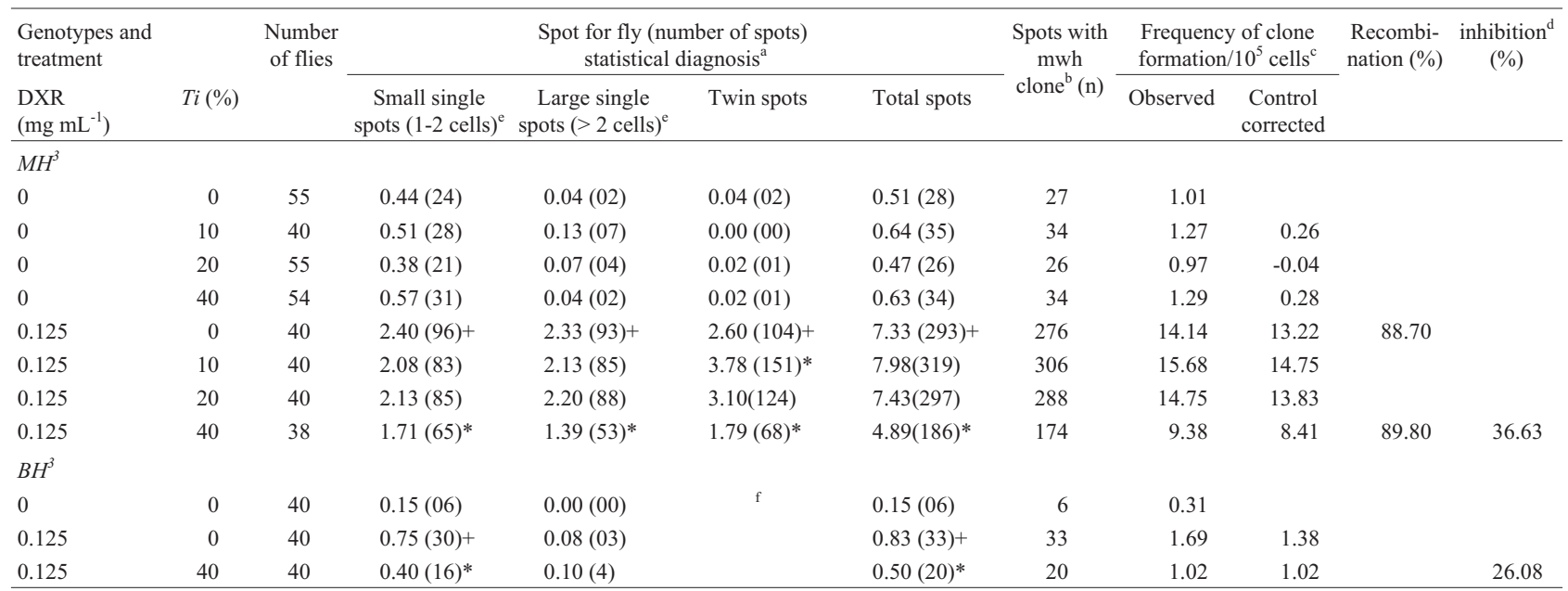

MH flies $\left(m w h / f l r^{3}\right)$ and BH flies ( $\left.m w h / T M 3\right)$ were evaluated. ${ }^{a}$ Statistical diagnoses according to Frei and Würgler (1995). U-test, two-sided, probability levels:,$+ \mathrm{p} \leq 0.05 \mathrm{vs}$. untreated control; *, $\mathrm{p} \leq 0.05 \mathrm{vs}$. DXR only. ${ }^{\mathrm{b}}$ Considering $m w h$ clones from $m w h$ single and twin spots. ${ }^{\mathrm{c}} \mathrm{Frequency}$ of clone formation: clones/flies/48,800 cells (without size correction). ${ }^{\mathrm{d}}$ Calculated as [DXR alone - (DXR + Ti)/ DXR alone] X 100, according to Abraham (1994). ${ }^{\mathrm{e}}$ Including rare $f l r^{3}$ single spots. ${ }^{\mathrm{f}}$ Only mwh single spots can be observed in BH individuals.

Table 2 - Summary of results obtained with the Drosophila wing spot test (SMART) in the marker-trans-heterozygous (MH) and balancer-heterozygous (BH) progeny of the high bioactivation (HB) cross after chronic treatment of larvae with Tabebuia impetiginosa (Ti) and doxorubicin (DXR).

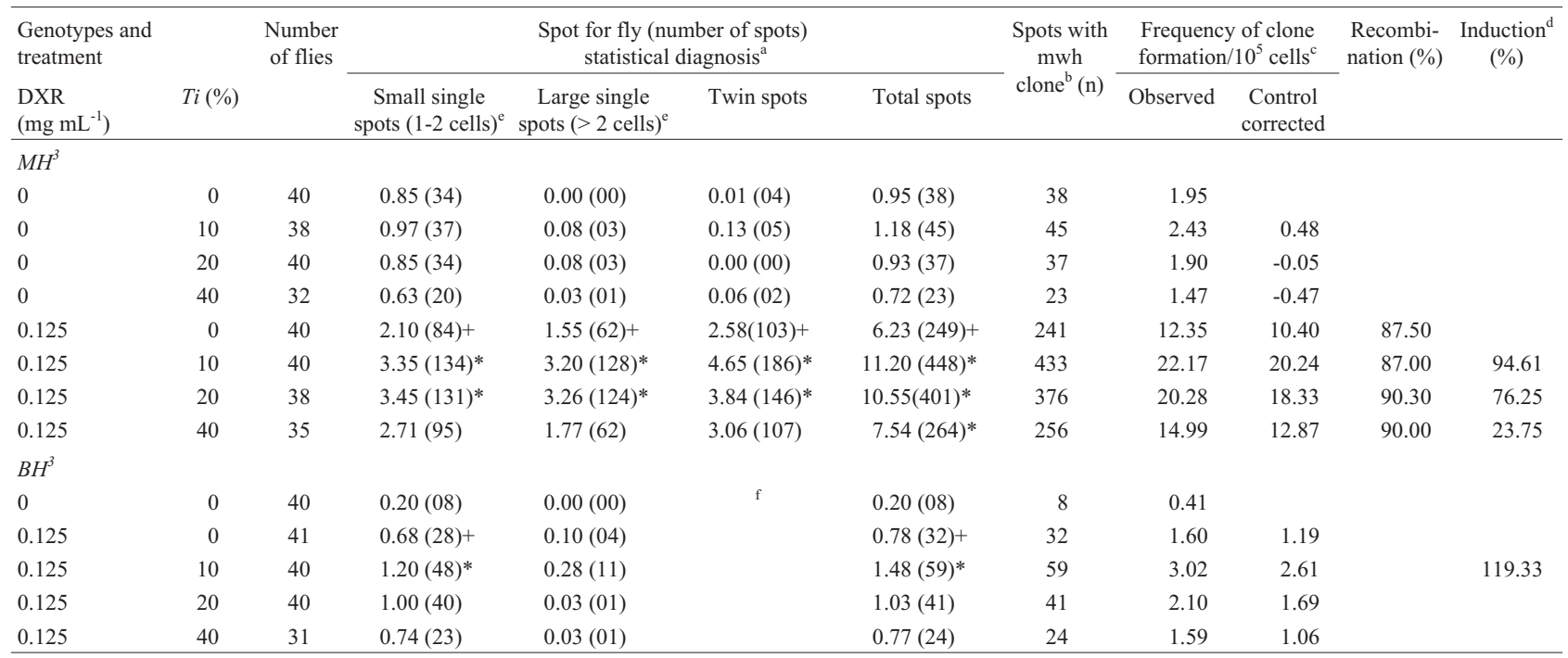

MH flies $\left(m w h / f l r^{3}\right)$ and BH flies ( $\left.m w h / T M 3\right)$ were evaluated. ${ }^{a}$ Statistical diagnoses according to Frei and Würgler (1995). $U$-test, two-sided, probability levels:,$+ \mathrm{p} \leq 0.05$ vs. untreated control; *, $\mathrm{p} \leq 0.05 \mathrm{vs}$. DXR only. ${ }^{\mathrm{b}}$ Considering $m w h$ clones from $m w h$ single and twin spots. ${ }^{\mathrm{c}} \mathrm{Frequency}$ of clone formation: clones/flies/48,800 cells (without size correction). ${ }^{\mathrm{d}}$ Calculated as [DXR alone - (DXR + Ti) / DXR alone] X 100, according to Abraham (1994). ${ }^{\mathrm{e}} \mathrm{In}-$

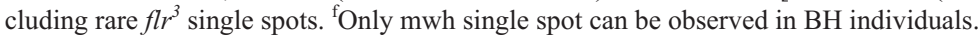

\section{Discussion}

Our study shows that a commercial preparation of powdered bark and stem of T. impetiginosa was toxic but did not induce somatic mutation and recombination in $D$. melanogaster from ST and HB crossbreeding. This means that $T$. impetiginosa alone neither acts as a genotoxin nor exerts any antigenotoxic effects on spontaneous DNA le- sions. Nevertheless, this toxicity is revealed by the diminished number of treated survivors.

DXR produced statistically significant induction of all categories of spots in both the ST and HB crossbreeds. These results are in line with those reported by Lehmann et al. (2003), Fragiorge et al. (2007), Pereira et al. (2008) and Valadares et al. (2008), who also demonstrated that DXR is a preferential inducer of homologous recombination, when 
compared with mutational events in D. melanogaster somatic cells.

As can be seen from the data in Table 1 on MH flies from the ST crossbreed, no differences were observed among the frequencies of total spots induced by co-treatments with $T$. impetiginosa $10 \%$ or $20 \%$ and DXR, when compared to those from the positive control (DXR alone). However, T. impetiginosa $40 \%$ in association with DXR displayed a $36.63 \%$ inhibition of DXR genotoxicity. Nevertheless, this is not interpreted as an antigenotoxic or protective effect of $T$. impetiginosa, since the number of survivor flies was reduced, thereby indicating $T$. impetiginosa toxicity which could be responsible for cell death or mitotic inhibition. According to Zeiger (2006), if the test concentrations used are near the stationary or toxic level on a plate test, a slight increase in toxicity could lead to lower survival rates, with a parallel decrease in mutant colonies. Such an apparent antimutagenic effect would therefore be the result of toxicity rather than antimutagenicity. The same should be true for the results found in the present study.

Herbal/dietary constituents may be metabolized by CYP into nontoxic metabolites and excreted, but the formation of toxic metabolites is possible. In addition, the inhibition of CYPs by herbal constituents may decrease the formation of toxic metabolites and thus inhibit carcinogenesis, as CYPs play an important role in procarcinogen activation. The bioactivation of herbal constituents appears to be a critical step for toxicity induction in some herbs. The resultant reactive intermediates bind covalently to DNA and proteins, leading to organ toxicity and even carcinogenicity. On the other hand, some herbal/dietary constituents were shown to form reactive intermediates capable of irreversibly inhibiting various CYPs (Zhou et al., 2004).

The results shown in Table 2 indicate the significant potentiating action of T. impetiginosa when administered simultaneously with DXR, and which was inversely proportional to the concentrations applied, once more indicating a dose-response correlationship with toxicity. $T$. impetiginosa $10 \%$ or $20 \%$ significantly increased DXRinduced genotoxicity, which affected all categories of spots. Nevertheless, in the case of T. impetiginosa $40 \%$, synergistic activity was not so pronounced, with the significant increase in DXR genotoxicity being limited to the frequency of total spots. The magnitude of comutagenicity was considerable, leading to enhancements from 23.75 to $94.61 \%$.

Medicinal herbs contain complex mixtures of thousands of components that can exert their action separately or synergistically (Cai et al., 2004; Romero-Jiménez et al., 2005). It has been well established that the formation of reactive drug metabolites is associated with drug toxicity. Similarly, data are accumulating which suggest the role of the formation of reactive metabolites/intermediates through bio-activation in herbal toxicity and carcinogenic- ity. It has been hypothesized that the resultant reactive metabolites following herbal bio-activation covalently bind to cellular proteins and DNA, thus leading to toxicity via multiple mechanisms such as direct cytotoxicity, oncogene activation and hypersensitivity reactions (Zhou et al., 2004).

The mechanisms used by $T$. impetiginosa to interact with the genotoxicity of DXR were not analyzed directly. The results observed in the present study allow us to hypothesize that: i) $T$. impetiginosa constituents may interact with those enzyme systems catalyzing the metabolic detoxification of DXR, leading to the enhancement of DXR mutagenicity; ii) $T$. impetiginosa constituents generate superoxide radicals and stimulate microsomal oxidation via NAD(P)H. Similar results and conclusions were described by Lehmann et al. (2000) with tannic acid in association with mitomycin $\mathrm{C}$, methylmethanesulfonate and nitrogen mustard in somatic cells of D. melanogaster.

Our findings demonstrated that powdered bark and stem of T. impetiginosa was toxic, but not genotoxic by itself, yet it possesses a considerable potentiating effect on DXR genotoxity, thereby suggesting that $T$. impetiginosa may possess anticarcinogenic potential. Therefore, further experiments, including carcinogenicity tests, are required on dose response, appropriate combinations, and potential toxicity/genotoxicity of $T$. impetiginosa associations with chemotherapeutic drugs, to determine the possible risks or protection that could be associated with the exposure of living organisms to this complex mixture.

\section{Acknowledgments}

This work was supported by the Conselho Nacional de Desenvolvimento Científico e Tecnológico (CNPq), Coordenação de Aperfeiçoamento de Pessoal de Nível Superior (CAPES), Fundação de Amparo à Pesquisa do Estado de Minas Gerais (FAPEMIG), and Universidade Federal de Uberlândia (UFU).

\section{References}

Abraham SK (1994) Antigenotoxicity of coffee in the Drosophila assay for somatic mutation and recombination. Mutagenesis 9:383-386.

Algranti E, Mendonça EM, Ali AA, Kokron CM and Raile V (2005). Occupational asthma caused by Ipê (Tabebuia spp) dust. J Invest Allergol Clin Immunol 15:81-83.

Almeida ER (1993) Plantas Medicinais Brasileiras: Conhecimentos Populares e Científicos. Hemus, São Paulo, 341 pp.

Anesini C and Perez C (1993) Screening of plants used in Argentine folk medicine for antimicrobial activity. J Ethnopharmacol 39:119-128.

Cai Y, Luo Q, Sun M and Corke H (2004) Antioxidant activity and phenolic compounds of 112 traditional Chinese medicinal plants associated with anticancer. Life Sci 74:21572184.

Dapkus J and Merrell DJ (1977) Chromosomal analysis of DDTresistance in a long-term selected population of Drosophila melanogaster. Genetics 87:685-697. 
Doroshow JH (1983) Effect of anthracycline antibiotics on oxygen radical formation in rat heart. Cancer Res 43:460-472.

Fonseca SGC, Braga RMC and Santana DP (2003) Lapachol Chemistry, pharmacology and assay methods. Rev Bras Farm 84:9-16.

Fragiorge EJ, Spanó MA and Antunes LMG (2007) Modulatory effects of the antioxidant ascorbic acid on the direct genotoxicity of doxorubicin in somatic cells of Drosophila melanogaster. Genet Mol Biol 30:449-455.

Frei H and Würgler FE (1988) Statistical methods to decide whether mutagenicity test data from Drosophila assays indicate a positive, negative or inconclusive result. Mutat Res 203:297-308

Frei H and Würgler FE (1995) Optimal experimental design and sample size for the statistical evaluation of data from somatic mutation and recombination test (SMART) in Drosophila. Mutat Res 334:247-258.

Frölich A and Würgler FE (1989) New tester strains with improved bioactivation capacity for the Drosophila wing-spot test. Mutat Res 216:179-187.

Frölich A and Würgler FE (1990) Genotoxicity of ethyl carbamate in the Drosophila wing spot test: Dependence on genotype-controlled metabolic capacity. Mutat Res 244:201-208.

Graf U and Singer D (1992) Genotoxicity testing of promutagens in the wing somatic mutation and recombination test in Drosophila melanogaster. Rev Int Contam Ambient 8:1527.

Graf U and van Schaik N (1992) Improved high bioactivation cross for the wing somatic mutation and recombination test in Drosophila melanogaster. Mutat Res 271:59-67.

Graf U, Würgler FE, Katz AJ, Frei J, Juon H, Hall CB and Kale PG (1984) Somatic mutation and recombination test in Drosophila melanogaster. Environ Mutagen 6:153-188.

Graf U, Frei H, Kägi A, Katz AJ and Würgler FE (1989) Thirty compounds tested in the Drosophila wing spot test. Mutat Res 222:359-373.

Graf U, Abraham SK, Guzmán-Rincón J and Würgler FE (1998) Antigenotoxicity studies in Drosophila melanogaster. Mutat Res 402:203-209.

Guzmán-Rincón J and Graf U (1995) Drosophila melanogaster somatic mutation and recombination test as a biomonitor. In: Butterworth FM, Corkun LD and Guzmán-Rincón J (eds) Biomonitors and Biomarkers of Environment Change. Plenum Press, New York, pp 169-181.

Hussain H, Krohn K, Ahmad VU, Miana GA and Green IR (2007) Lapachol: An overview. Arkivoc ii:145-171.

Koyama J, Morita I, Tagahara K and Hirai K (2000) Cyclopentene dialdehydes from Tabebuia impetiginosa. Phytochemistry 53:869-872.

Lehmann M, Graf U, Reguly ML and Andrade HHR (2000) Interference of tannic acid on the genotoxicity of mitomycin C, methylmethanesulfonate, and nitrogen mustard in somatic cells of Drosophila melanogaster. Environ Mol Mutagen 36:195-200.

Lehmann M, Franco A, Vilar KSP, Reguly ML and Andrade HHR (2003) Doxorubicin and two of its analogues are preferential inducers of homologous recombination compared with mutational events in somatic cells of Drosophila melanogaster. Mutat Res 539:167-175.

Lindsley DL and Zimm GG (1992) The Genome of Drosophila melanogaster. Academic Press, San Diego, 1133 pp.
Menna-Barreto RFS, Henriques-Pons A, Pinto AV, MorgadoDiaz JA, Soares MJ and De Castro SL (2005) Effect of a $\beta$-Lapachone-derived naphthoimidazole on Trypanosoma cruzi: Identification of target organelles. J Antimicrob Chemother 56:1034-1041.

Müller K, Sellmer A and Wiegrebe W (1999) Potential antipsoriatic agents: Lapacho compounds as potent inhibitors of HaCaT cell growth. J Nat Prod 62:1134-1136.

Park BS, Lee KG, Shibamoto T, Lee SE and Takeoka GR (2003) Antioxidant activity and characterization of volatile constituents of Taheebo (Tabebuia impetiginosa Martius ex DC). J Agricult Food Chem 51:295-300.

Park BS, Kim JR, Lee SE, Kim KS, Takeoka GR, Ahn YJ and Kim JH (2005) Selective growth-inhibiting effects of compounds identified in Tabebuia impetiginosa inner bark on human intestinal bacteria. J Agricult Food Chem 53:11521157.

Park HJ, Lee H, Lee S, Piao X, Takeoka GR, Wong RY, Ahn Y and Kim J (2006) Antibacterial activity of Tabebuia impetiginosa Martius ex DC (Taheebo) against Helicobacter pylori. J Ethnopharmacol 105:255-262.

Pereira DG, Antunes LMG, Graf U and Spanó MA (2008) Protection by Panax ginseng C.A. Meyer against the genotoxicity of doxorubicin in somatic cells of Drosophila melanogaster. Genet Mol Biol 31:947-955.

Romero-Jiménez M, Campos-Sánchez J, Analla M, Muñoz-Serrano A and Alonso-Moraga A (2005) Genotoxicity and anti-genotoxicity of some traditional medicinal herbs. Mutat Res 585:147-155.

Santos JH, Graf U, Reguly ML and Andrade HHR (1999) The synergistic effects of vanillin on recombination predominate over its antimutagenic action in relation to MMC-induced lesions in somatic cells of Drosophila melanogaster. Mutat Res 444:355-365.

Savage RE, Tyler AN, Miao XS and Chan TC. (2008) Identification of a novel glucosylsulfate conjugate as a metabolite of 3,4-dihydro-2,2-dimethyl-2H-naphtho[1,2-b]pyran-5,6-dio ne (ARQ 501, beta-lapachone) in mammals. Drug Metab Dispos 36:753-758.

Silva RMG, Sousa NC, Graf U and Spanó MA (2008) Antigenotoxic effects of crude extract from Mandevilla velutina (Mart. ex Stadelm.) Woodson (Apocinaceae) on cyclophosphamide-induced micronuclei in mice and urethane-induced somatic mutation and recombination in Drosophila melanogaster. Genet Mol Biol 31:751-758.

Sinigaglia M, Lehmann M, Baumgardt P, Amaral VS, Dihl RR, Reguly ML and Andrade HHR (2006) Vanillin as a modulator agent in SMART test: Inhibition in the steps that precede $N$-methyl- $N$-nitrosourea-, $N$-ethyl- $N$-nitrosourea-, ethylmethanesulphonate- and bleomycin-genotoxicity. Mutat Res 607:225-230.

Son DJ, Lim Y, Park YH, Chang SK, Yun YP, Hong JT, Takeoka GR, Lee KG, Lee SE, Kim MR, et al. (2006) Inhibitory effects of Tabebuia impetiginosa inner bark extract on platelet aggregation and vascular smooth muscle cell proliferation through suppressions of arachidonic acid liberation and ERK1/2 MAPK activation. J Ethnopharmacol 108:48-151.

Sousa NC, Carvalho S, Spanó MA and GRAF U (2003). Absence of genotoxicity of a phytotherapeutic extract from Stryphnodendron adstringens (Mart.) Coville in somatic 
and germ cells of Drosophila melanogaster. Environ Mol Mutagen 41:293-299.

Spanó MA, Frei H, Würgler FE and Graf U (2001) Recombinogenic activity of four compounds in the standard and high bioactivation crosses of Drosophila melanogaster in the wing spot test. Mutagenesis 16:385-394.

Swift LP, Cutts SM, Nudelman A, Levovich I, Rephaeli A and Phillips DR (2008) The cardio-protecting agent and topoisomerase II catalytic inhibitor sobuzoxane enhances doxorubicin-DNA adduct mediated cytotoxicity. Cancer Chemother Pharmacol 61:739-749.

Valadares BLB, Graf U and Spanó MA (2008) Inhibitory effects of water extract of propolis on doxorubicin-induced somatic mutation and recombination in Drosophila melanogaster. Food Chem Toxicol 46:1103-1110.

Vogel EW, Graf U, Frei HJ and Nivard MM (1999) The results of assays in Drosophila as indicators of exposure to carcinogens. IARC Sci Publ 146:427-470.

Warashina T, Nagatani Y and Noro T (2004) Constituents from the bark of Tabebuia impetiginosa. Phytochemistry 65:2003-2011.
Warashina T, Nagatani Y and Noro T (2005) Further constituents from the bark of Tabebuia impetiginosa. Phytochemistry 66:589-597.

Warashina T, Nagatani Y and Noro T (2006) Constituents from the bark of Tabebuia impetiginosa. Chem Pharm Bull (Tokyo) 54:14-20.

Yamashita M, Kaneko M, Lida A, Tokuda H and Nishimura K (2007) Stereoselective synthesis and cytotoxicity of a cancer chemopreventive naphthoquinone from Tabebuia avellanedae. Bioorg Med Chem Lett 17:6417-6420.

Zani CL, Oliveira AB and Oliveira GG (1991) Furanonaphthoquinones from Tabebuia ochracea. Phytochemistry 30:2379-2381.

Zeiger E (2006) What is needed for an acceptable antimutagenicity manuscript? Mutat Res 626:1-3.

Zhou S, Koh H-L, Gao Y, Gong Z and Lee EJD (2004) Herbal bioactivation: The good, the bad and the ugly. Life Sci 74:935-968.

Associate Editor: Carlos F.M. Menck

License information: This is an open-access article distributed under the terms of the Creative Commons Attribution License, which permits unrestricted use, distribution, and reproduction in any medium, provided the original work is properly cited. 